\begin{tabular}{|c|c|c|}
\hline & Journal STAND: Sports and Development \\
unima Smadamy & $\begin{array}{c}\text { http://jurnal.unipasby.ac.id/index.php/stand/about/submissions } \\
\text { jurnal.stand@unipasby.ac.id }\end{array}$ \\
\hline
\end{tabular}

\title{
DAMPAK PANDEMI COVID-19 TERHAPAD PELAKSANAAN PEMBELAJARAN PENJAS ADAPTIF DI SEKOLAH LUAR BIASA
}

\author{
Muhammad Nurrohman Jauhari ${ }^{1}$, Sambira ${ }^{2}$, Zykra Zakiah ${ }^{3}$ \\ ${ }^{1,2}$ Pendidikan Khusus - Universitas PGRI Adi Buana \\ ${ }^{3}$ Pendidikan Khusus - Universitas Negeri Yogyakarta \\ Email :mnjauhari@unipasby.ac.id ${ }^{1}$, sambira@unipasby.ac.id ${ }^{2}$, zykrazakiah@uny.ac.id ${ }^{3}$
}

\section{Artikel Info \\ Koresponden penulis: \\ Muhammad Nurrohman Jauhari \\ Email: mnjauhari@unipasby.ac.id}

Diterima 27 April 2020

Direview 13 Mei 2020

Disetujui 19 Mei 2020

Dipublikasi 27 Mei 2020

\begin{abstract}
Abstrak
Tujuan dari penelitian ini untuk mengetahui dampak pandemi covid-19 terhadap pelaksanaan pembelajaran penjas adaptif di sekolah luar biasa. Penelitian menggunakan metode kualitatif yang menghasilkan data berupa ungkapan seseorang yang mengarah pada suatu keadaan tertentu. Hasil dari penelitian bahwa guru pendidikan jasmani adaptif dalam melaksanakan pembelajaran kepada anak berkebutuhan khusus mengalami hambatan pada pelaksanaan praktik program pendidikan jasmani adaptif, dan arana prasarana yang kurang memadai
\end{abstract}

\begin{abstract}
The purpose of this study was to determine the impact of the Covid-19 pandemic on the implementation adaptive sport in special schools. This research uses qualitative methods that produce data in the form of a person's expressions that lead to a certain situation. The results of the study show that adaptive sport teachers in implementing learning to children with special needs in the implementation of adaptive physical education program practices, and accessibility.
\end{abstract}

\section{Keywords:}




\begin{tabular}{|c|c|c|}
\hline Journal STAND: Sports and Development \\
\hline unipa Sumalaya & $\mathrm{http}: / /$ jurnal.unipasby.ac.id/index.php/stand/about/submissions \\
\hline
\end{tabular}

\section{PENDAhuluAN}

Coronaviruses merupakan virus yang menyebabkan penyakit mulai dari flu biasa hingga penyakit yang lebih parah (Covid-19, 2020). Gejala yang ditemukan seperti demam, batuk, sesak napas dan kesulitan bernafas. Pada kasus yang lebih parah, infeksi dapat menyebabkan pneumonia, sindrom pernapasan akut, gagal ginjal, dan bahkan kematian. Kasus positif covid-19 pertama di Indonesia terjadi pada bulan Maret 2020 kemudian beberapa bulan kemudian meyebar sampai 34 provinsi di Indonesia (Djalante et al., 2020). Kasus positif di Indonesia semakin hari semakin bertambah sehingga pemerintah menetapkan kasus tersebut sebagai bencana nasional. Dalam menekan penyebaran kasus positif covid-19 pemerintah memberikan himbauan untuk menjaga jarak, memakai masker dan cuci tangan (Ardan, Rahman, \& Geroda, 2020)

Pandemi covid-19 di Indonesia berdampak pada bidang ekonomi, sosial, wirausaha, pekerjaan serta pada bidang pendidikan. Dalam bidang pendidikan pemerintah dalam hal ini Kementerian Pendidikan dan Kebudayaan mengambil kebijakan untuk pelaksanaan pembelajaran dilaksanakan dari rumah (Pujilestari, 2020). Sekolah yang harus melaksanakan Belajar Dari Rumah (BDR) antara lain Sekolah
Dasar (SD), Madrasah Ibtidaiyah (MI), Sekolah Menengah Pertama (SMP), Madrasah Tsanawiyah (MTs), Sekolah Menengah Atas (SMA), Madrasah Aliyah (MA), Sekolah Menengah Kejuruan (SMK) serta sekolah inklusi dan Sekolah Luar Biasa (SLB) pada tingkat Dasar, Mengengah dan Atas. Pelaksanaan pembelajaran yang biasanya dilaksanakan tatap muka berubah menjadi Belajar Dari Rumah (BDR). Metode pelaksanaan BDR dibagi menjadi 2 yaitu pembelajaran dalam jaringan (daring) dengan menggunakan handphone, laptop, aplikasi pembelajaran dan pembelajaran luar jaringan (luring) menggunakan media radio, televisi, modul, lembar kerja siswa.

Sekolah luar biasa merupakan sekolah khusus bagi anak berkebutuhan khusus yang bertujuan untuk memberikan kesempatan bagi anak dalam memperoleh pendidikan (Pramartha, 2015). Pada sekolah luar biasa pelaksanaan pembelajaran untuk anak berkebutuhan khusus memiliki karakteristik pembelajaran tersendiri. Anak berkebutuhan khusus yang dimaksudkan antara lain tunarungu adalah anak yang mengalami hambatan pendengaran, tunanetra adalah anak yang mengalami hambatan pengelihatan, tunagrahita adalah anak yang mengalami hambatan intelegensi, tunadaksa anak yang mengalami hambatan motorik dan autis anak yang mengalami hambatan 
komunikasi, perilaku dan interaksi sosial (Jauhari, 2017). Masalah yang dihadapi guru sekolah luar biasa dalam pembelajaran daring yaitu pada sarana dan prasarana seperti sinyal, media pembelajaran online, aplikasi pembelajaran, kuota internet dan pembelajaran berbasis praktik. Pembelajaran praktik merupakan suatu proses untuk meningkatkan keterampilan peserta didik dengan menggunakan berbagai metode yang sesuai dengan keterampilan yang diberikan dan peralatan yang digunakan. Hal ini mengakibatkan peserta didik berkebutuhan khusus ada yang melaksanakan pembelajaran daring dan ada yang tidak melaksanakan pembelajaran sama sekali (Dewi, 2020).

Di masa pandemi covid 19 ini guru penjas di sekolah luar biasa memiliki cara sendiri dalam melaksanakan pembelajaran penjas adaptif disekolah masing-masing. Pendidikan jasmani adaptif merupakan pendidikan jasmani yang dimodifikasi berdasarkan karakteristik anak berkebutuhan khusus untuk mengembangkan aktivitas gerak (Fefrian, Mardhika, Santika, \& Sumardi, 2020).

\section{METODE PENELITIAN}

Jenis Penelitian ini menggunakan metode kualitatif yang menghasilkan data berupa ungkapan seseorang yang mengarah pada suatu keadaan tertentu. Penelitian kualitatif adalah penelitian yang dilakukan untuk mengetahui fenomena dil apangan oleh subjek penelitian dengan cara deskripsi dalam bentuk kata-kata dan bahasa berdasarkan hasil pengamatan (Raco, 2018). Landasan teori yang digunakan berdasarkan fakta yang terjadi di lapangan. Dalam pelaksanaannya menggunakan angket (google form) yang disebar kepada 50 guru penjas di Sekolah Luar Biasa (SLB).

\section{HASIL DAN PEMBAHASAN}

Pelaksanaan pembelajaran penjas adaptif di sekolah luar biasa yang dilakukan oleh guru pendidikan jasmani antara lain:

a. Pelaksanaan pembelajaran daring

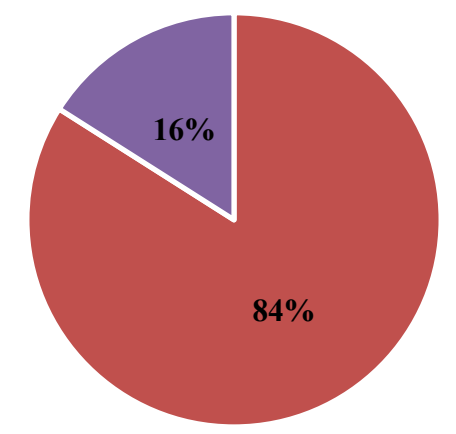

- Melaksanakan - Tidak Melaksanakan

Gambar 1. Pelaksanaan pembelajaran

Dari 50 responden guru pendidikan jasmani di sekolah luar biasa berdasarkan hasil angket yang disebar didapatkan sebanyak (84\%) 42 guru pendidikan jasmani di sekolah luar biasa melaksanakan pembelajaran jarak jauh atau Belajar Dari 
Rumah (BDR) sedangkan (16\%) 8 guru pendidikan jasmani di sekolah luar biasa tidak melaksanakan pembelajaran jarak jauh atau Belajar Dari Rumah (BDR). Permasalahan yang dihadapi guru pendidikan jasmani yang tidak melaksanakan pembelajaran dari rumah karena 1). kurangnya pengetahuan guru dalam menggunakan zoom meeting, google meet dan aplikasi pembelajaran lainnya, Hal tersebut didasarkan pada kurangnya pelatihan bagi guru sekolah luar biasa tentang penggunaan aplikasi pembelajaran berbasis IT (Kusuma \& Hamidah, 2020); 2). Keterbatasan kuota internet, 3). Tidak memiliki smartphone; 4). Jaringan internet 5). Guru pendidikan jasmani merasa kurang efektif dalam melaksanakan pembelajaran dari rumah. Hal tersebut dikarenakan pelaksanaan pendidikan jasmani berdasarkan pada praktik untuk menumbuhkan aktivitas gerak pada anak berkebutuhan khusus, 6). Kurangnya komunikasi antar guru dan orangtua anak berkebutuhan khusus, Koordinasi dan komunikasi antara guru sekolah luar biasa dan orang tua anak berkebutuhan khusus memiliki peran penting dalam membuat program Latihan dan pelaksanaan pembelajaran dari rumah. Dalam hal ini Kementerian Pendidikan dan Kebudayaan memberikan surat edaran Nomor 4 tahun 2020 tentang pelaksanaan kebijakan pendidikan dalam masa darurat penyebaran covid-19 yang didalamnya menjabarkan tentang a). Belajar dari Rumah melalui pembelajaran daring/jarak jauh dilaksanakan untuk memberikan pengalaman belajar yang bermakna bagi siswa, tanpa terbebani tuntutan menuntaskan seluruh capaian kurikulum untuk kenaikan kelas maupun keluiusan; b). Belajar dari Rumah dapat difokuskan pada pendidikan kecakapan hidup antara lain mengenai pandemi Covid19; c). Aktivitas dan tugas pembelajaran Belajar dari Rumah dapat bervariasi antarsiswa, sesuai minat dan kondisi masingmasing, termasuk mempertimbangkan kesenjangan akses/ fasilitas belajar di rumah; d). Bukti atau produk aktivitas Belajar dari Rumah diberi umpan baiik yang bersifat kualitatif dan berguna dari guru, tanpa diharuskan memberi skor/nilai kuantitatif.

b. Perangkat pembelajaran

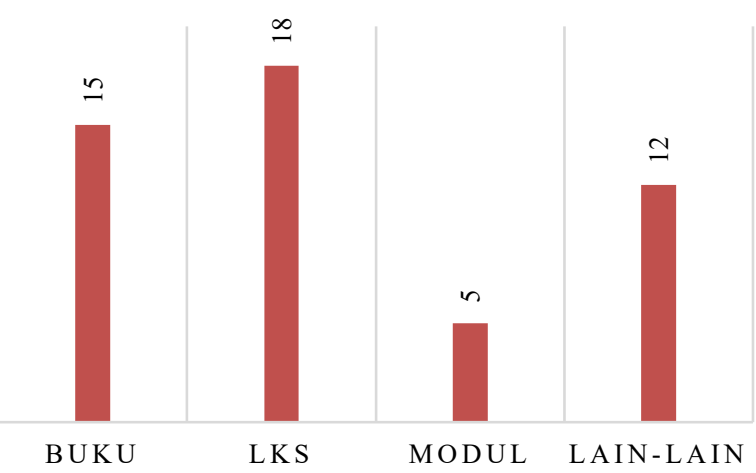

Gambar 2. Perangkat pembelajaran 
Perangkat pembelajaran yang digunakan oleh guru pendidikan jasmani sebanyak 15 guru menggunakan buku guru dan siswa, 18 guru menggunakan Lembar Kerja Siswa (LKS), sebanyak 5 guru menggunakan modul dan 12 guru menggunakan lain-lain. Pada hal lain-lain tersebut guru pendidikan jasmani di sekolah luar biasa menggunakan aplikasi pembelajaran, video tutorial, dan program Latihan penjas adaptif (Herlina \& Suherman, 2020)h.

Perangkat pembelajaran merupakan pedoman atau petunjuk bagi guru dalam melaksanakan pembelajaran yang dapat disiapkan oleh guru maupun dari pihak lainnya. Standar kompetensi yang diajarakan kepada anak berkebutuhan khusus berfokus pada karaakteristik dan kemampuan yang dimiliki . Pada pendidikan jasmani adaptif bagi anak berkebutuhan khusus berfokus pada peningkatan kondisi anak berkebutuhan khusus (Kesumawati \& Damanik, 2019), memberikan kesempatan bagi anak berkebutuhan khusus dalam berpartisipasi dalam olahraga, serta memberikan pengetahuan bagi anak berkebutuhan khusus mengenai olahraga. Berdasarkan penelitian (Rahmawati, 2013) Pengaruh pendekatan bermain dalam pembelajaran penjas adaptif terhadap keterampilan gerak lokomotor dan manipulatif siswa tunanetra didapatkan hasil bahwa penerapan pembelajaran penjas adaptif berpengaruh secara signifikan terhadap keterampilan gerak dasar siswa tunanetra low vision.

c. Metode pelaksanaan pembelajaran

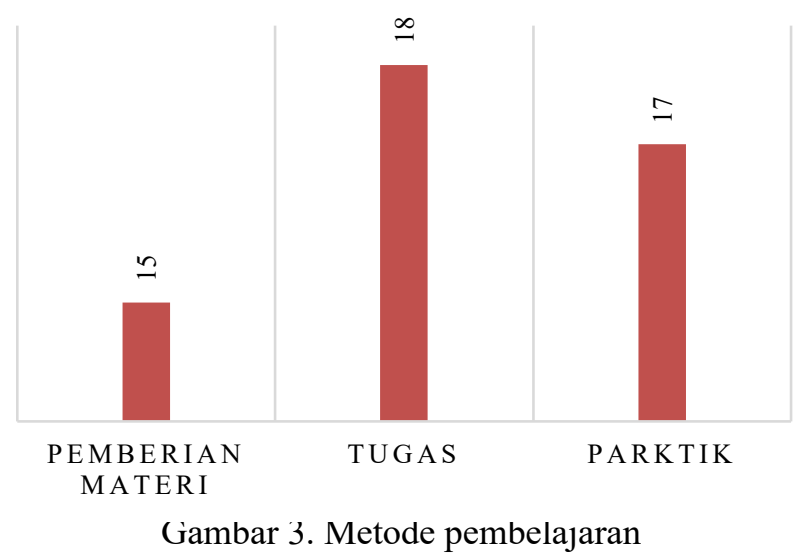

Metode pelaksanaan pembelajaran yang digunakan guru pendidikan jasmani di sekolah luar biasa antara lain sebanyak 15 guru memberikan materi melalui whatsapp, sebanyak 18 guru hanya memberikan tugas kepada anak berkebutuhan khusus dikarenakan sarana dan prasarana yang kurang memadai dan 17 guru memberikan tugas praktek kepada anak berkebutuhan khusus. Guru pendidikan jasmani di sekolah inklusi memberikan tugas pada anak berkebutuhan khusus untuk praktik oleh raga di setiap pagi. Guru melaksanakan koordinasi dengan orangtua untuk membuat video aktivitas olahraga yang dilakukan oleh anak berkebutuhan khusus (Taufan, Ardisal, Damri, \& Arise, 2018). Pendidikan jasmani adaptif merupakan proses pembelajaran yang 
dilaksanakan untuk meningkatkan kebugaran jasmani, meningkatkan kemampuan gerak, pengetahuan dan perilaku hidup aktif dan sikap positif melalui kegiatan jasmani (Putri, Marzuki, \& Purnomo, 2013)

Pendidikan jasmani adaptif yang diajarkan di sekolah memiliki peranan yang sangat penting (Rosmi, 2016), yaitu memberikan kesempatan kepada peserta didik untuk terlibat langsung dalam berbagai pengalaman belajar melalui aktivitas jasmani yang terpilih serta dilakukan secara sistematis. Pendidikan jasmani selain untuk kesehatan juga harus mengandung aspek yang sesuai dengan tumbuh kembang peserta didik (Muhtar \& Lengkana, 2019)

\section{KESIMPULAN}

Hasil dari penelitian bahwa guru pendidikan jasmani adaptif dalam melaksanakan pembelajaran kepada anak berkebutuhan khusus mengalami hambatan pada pelaksanaan praktik program pendidikan jasmani adaptif, sarana prasarana serta aksesibilitas yang kurang memadai.

\section{REFERENSI}

Ardan, M., Rahman, F. F., \& Geroda, G. B. (2020). THE INFLUENCE OF PHYSICAL DISTANCE TO STUDENT ANXIETY ON COVID-19, INDONESIA. Journal of Critical Reviews, 7(17), 1126-1132.

Covid-19, G. T. (2020). Protokol Percepatan Penanganan Pandemi
Covid-19 (Corona Virus Disease 2019). 19, 31.

Dewi, W. A. F. (2020). Dampak COVID-19 terhadap Implementasi Pembelajaran Daring di Sekolah Dasar. Edukatif: Jurnal Ilmu Pendidikan, 2(1), 55-61. https://doi.org/10.31004/edukatif.v2i1.8 9

Djalante, R., Lassa, J., Setiamarga, D., Mahfud, C., Sudjatma, A., Indrawan, M., ... Djalante, S. (2020). Review and analysis of current responses to COVID-19 in Indonesia: Period of January to March 2020. Progress in Disaster Science, 100091.

Fefrian, Y., Mardhika, R., Santika, R. H., \& Sumardi, S. (2020). Penjas Adaptif Bagi Guru Sekolah Luar Biasa (SLB) Siswa Budhi Surabaya. SPEED Journal: Journal of Special Education, 3(2), 101-106.

Herlina, H., \& Suherman, M. (2020). Potensi Pembelajaran Pendidikan Jasmani Olahraga dan Kesehatan (PJOK) di Tengah Pandemi Corona Virus Disease (COVID)-19 di Sekolah Dasar. Tadulako Journal Sport Sciences And Physical Education, 8(1), 1-7.

Jauhari, M. N. (2017). Pengetahuan Mahasiswa PG-Paud UNIPA Surabaya Tentang Anak Berkebutuhan Khusus. Buana Pendidikan: Jurnal Fakultas Keguruan Dan Ilmu Pendidikan, 13(24), 165-177.

Kesumawati, S. A., \& Damanik, S. A. (2019). MODEL PEMBELAJARAN GERAK DASAR PADA ANAK TUNAGRAHITA RINGAN. JURNAL ILMU KEOLAHRAGAAN, 18(2), 146153.

Kusuma, J. W., \& Hamidah, H. (2020). PERBANDINGAN HASIL BELAJAR MATEMATIKA DENGAN PENGGUNAAN PLATFORM WHATSAPP GROUP DAN WEBINAR ZOOM DALAM 
PEMBELAJARAN JARAK JAUH

PADA MASA PANDEMIK COVID

19. JIPMat, 5(1).

Muhtar, T., \& Lengkana, A. S. (2019).

Pendidikan jasmani dan olahraga

adaptif. UPI Sumedang Press.

Pramartha, I. N. B. (2015). Sejarah Dan

Sistem Pendidikan Sekolah Luar Biasa

Bagian a Negeri Denpasar Bali.

HISTORIA: Jurnal Program Studi

Pendidikan Sejarah, 3(2), 67-74.

Pujilestari, Y. (2020). Dampak Positif

Pembelajaran Online Dalam Sistem

Pendidikan Indonesia Pasca Pandemi

Covid-19. 'ADALAH, 4(1).

Putri, W. U., Marzuki, M., \& Purnomo, E.

(2013). Strategi Pembelajaran

Pendidikan Jasmani Adaptif Bagi

Murid Berkebutuhan Khusus di Sekolah

Luar Biasa $C$. Tanjungpura University.

Raco, J. (2018). Metode penelitian

kualitatif: jenis, karakteristik dan

keunggulannya.

Rahmawati, I. (2013). PENERAPAN

PENDEKATAN FLOOR TIME UNTUK

MENINGKATKAN HASIL BELAJAR

PENJAS ADAPTIF PADA SISWA

TUNALARAS: Penelitian Tindakan

Kelas Pada Siswa Kelas VA Di SLB E

Prayuwana Yogyakarta. Universitas

Pendidikan Indonesia.

Rosmi, Y. F. (2016). Pendidikan Jasmani

Dan Pengembangan Karakter Siswa

Sekolah Dasar. WAHANA, 66(1), 5561.

Taufan, J., Ardisal, A., Damri, D., \& Arise, A. (2018). Pelaksanaan Pembelajaran Pendidikan Jasmani Adaptif bagi Anak dengan Hambatan Fisik dan Motorik. Jurnal Pendidikan Kebutuhan Khusus, 2(2), 19-24. 